\title{
PENGARUH PENYALURAN DANA BMT TERHADAP KESEJAHTERAAN \\ MASYARAKAT BOGOR \\ (PERIODE TAHUN 2008-2011)
}

Oleh:

Muhammad Findi A*

Sarah Asy Syahidah Ajjahdah**

\begin{abstract}
Abstraksi
Penelitian ini dilatarbelakangi oleh permasalahan usaha mikro yang sulit mendapatkan bantuan dana/modal dari lembaga keuangan baik itu perbankan atau pun lembaga keuangan mikro syariah seperti Baitul Maal Wattamwil (BMT). Didasarkan pada hal diatas peneliti kemudian mencoba meneliti bagaimanakah pengaruh penyaluran dana yang diberikan oleh BMT sebagai lembaga keuangan mikro syariah kepada masyarakat kecil yang membutuhkan bantuan permodalan dalam meningkatkan kesejahteraan atau peningkatan pendapatan mereka.

Dengan regresi linear berganda, peneliti mencoba melihat pengaruh penyaluran dana yang diberikan oleh BMT terhadap peningkatan kesejahteraan dalam hal pertumbuhan pendapatan anggota/nasabah. Variabel yang digunakan dalam penelitian ini adalah peningkatan pendapatan masyarakat, penyaluran dana/pembiayaan (pembiayaan mudharabah, pembiayaan musyarakah, pembiayaan murabahah dan pembiayaan al-qardh).

Dan hasil penelitian menunjukan bahwa seluruh variable penyaluran dana (pembiayaan mudharabah, pembiayaan musyarakah, pembiayaan murabahah dan pembiayaan al-qardh) memiliki pengaruh yang signifikan terhadap variable peningkatan pendapatan masyarakat di BMT wilayah Bogor.
\end{abstract}

Kata Kunci: Penyaluran Dana BMT, Pendapatan Masyarakat

\section{A. Pendahuluan}

Berdirinya lembaga keuangan Islam didasari oleh kenyataan adanya praktek sistem bunga, dimana sistem bunga itu dilarang oleh agama Islam. Sistem bunga adalah tambahan pembayaran atas uang pokok pinjaman. Berdasarkan batasan tersebut, pengertian bunga adalah imbal jasa atas pinjaman uang. Imbal jasa ini merupakan suatu kompensasi kepada pemberi pinjaman atas manfaat kedepan dari uang pinjaman tersebut apabila diinvestasikan.

Bidang ekonomi, yang merupakan salahsatu tulangpunggung tegaknya tatanan masyarakat yang dinamis, mendapat perhatian yang khusus dalam konsep Islam. Islam sangat memperhatikan dari atau bagaimana harta (hasil kegiatan ekonomi) itu diperoleh dan untuk apa harta itu digunakan. Terlebih sudah jelas tertera dalam firman Allah dalam surah AlBaqarah ayat 275 yang artinya: “...Allah telah menghalalkan jual-beli dan mengharamkan riba..." dimana manusia dimuka bumi diharuskan untuk memperoleh hartanya dengan cara yang baik dan halal, tidak dengan cara-cara yang tidak diridhai Allah seperti, berjudi, menipu, menjual barang haram dan masalah-masalah yang dikarenakan riba.

Perbankan yang ada saat ini dikatakan tidak berhasil dalam upaya pemerataan pendapatan karena pranata pembayaran bunga tetap menjamin dari debitur secara terus menerus ke arah kreditur. Jumlah debitur semakin lebih banyak daripada jumlah kreditur. 
Peminjaman yang diperoleh pada umumnya menjadi nilai tambah bagi debitur untuk membayar bunga kepada kreditur, terutama untuk jenis pinjaman yang bersifat konsumtif. Oleh karena itu, perbankan dengan pranata bunga menciptakan suatu keadaan yang kaya semakin kaya, dan yang miskin semakin miskin.

Beroperasinya lembaga keuangan yang berdasarkan prinsip syari'at Islam diharapkan mempunyai pengaruh yang besar terhadap terwujudnya ekonomi Islam. Ekonomi Islam adalah pemahaman/keyakinan ekonomi yang terjadi setelah prinsip ekonomi yang menjadi pedoman kerjanya dipengaruhi atau dibatasi oleh ajaran Islam. Sehingga ekonomi Islam bukanlah suatu pemikiran yang bersifat final melainkan terus berkembang melalui kerja ijtihad. ${ }^{1}$

Dalam sejarah perekonomian umat Islam, sebenarnya terdapat salah satu instansi yang telah memperhatikan aspek kebajikan pada kehidupan masyarakat, yaitu baitul maal yang memberikan kontribusi yang sangat signifikan dalam menyeimbangkan perekonomian umat Islam pada masa itu dengan memberikan dana subsidi kepada umat Islam yang membutuhkan yang dalam Islam dikenal dengan sebutan sebagai mustahik. Adapun sumber dana dari baitul maal tersebut adalah dari dana zakat, infak, pajak dan beberapa kebijakan yang telah ditentukan oleh khalifah (pemimpin) umat Islam pada waktu itu.

Baitul Maal Wattamwil (BMT) merupakan lembaga ekonomi Islam yang dibangun berbasis keumatan, sebab

* Dosen FEM IPB, dan Peneliti Pusat Studi Bisnis dan Ekonomi Syariah (PSBES) IPB

** Sarjana Ekonomi Islam, Alumnus STEI Tazkia Bogor

1 www.bi.go.id, yang diakses pada tanggal 05 Maret 2012 dibentuk dari, oleh dan untuk masyarakat. Baitul Maal Wattamwil yang lebih dikenal dengan BMT yang dimotori pertama kalinya oleh BMT Bina Insan Kamil tahun 1992 di Jakarta. Kendati awalnya hanya merupakan Kelompok Swadaya Masyarakat Syari'ah (KSM) namun demikian memiliki kinerja layaknya sebuah bank.

Dari segi jumlah, BMT pun merupakan lembaga keuangan syariah yang paling banyak apabila dibandingkan dengan lembaga-lembaga keuangan syariah lainnya. Kehadiran BMT di Indonesia, selain ditujukan untuk meningkatkan taraf hidup dan kesejahteraan masyarakat dibidang ekonomi, juga memiliki misi penting dalam meningkatkan kesejahteraan masyarakat di sekitarnya. Hal ini didasarkan pada visi BMT bahwa pembangunan ekonomi hendaknya dibangun dari bawah melalui kemitraan usaha.

Pemberian pembiayaan atau pinjaman merupakan salah satu cara atau alternative yang ditawarkan oleh BMT yang terdapat di wilayah Bogor kepada nasabahnya dalam membantu meningkatkan pendapatan nasabahnya tanpa memberatkan nasabahnya dengan system bunga yang biasa dipergunakan perbankan, terlebih lagi sasaran dari BMT adalah masyarakat kecil, khususnya pedagang kaki lima.

Oleh karena itu, dibutuhkannya BMT yang menjadi salahsatu mediator untuk meningkatkan kesejahteraan masyarakat. Dengan penyaluran dana yang dilakukan pihak BMT kepada masyarakat, hal itu dapat membantu masyarakat agar lebih berproduktif lagi. Terlebih fungsi dari BMT salah satunya adalah untuk mensejahterakan masyarakat. Dengan bantuan dari pihak pemerintah, fungsi BMT ini akan lebih dapat terealisasikan secara optimal. 
Pada peran lembaga mikro ini, tentunya dalam fungsi BMT untuk kesejahteraan sosial masyarakat, sampai saat ini masyarakat kita masih jauh dari harapan atas kemerdekaan, yaitu mendapatkan keadilan dan kesejahteraan. Pada kenyataannya, kesejahteraan hanya diperuntukan bagi orang kaya dan para pejabat saja, sedangkan masyarakat hanya bisa menjadi penonton tanpa menikmati sedikit pun.

Berdasarkan Pusat Inkubasi Usaha Kecil (PINBUK) pernah mengungkapkan data dan memiliki daftar rinciannya bahwa sampai dengan pertengahan tahun 2006, terdapat sekitar 3200 BMT yang beroperasi di Indonesia. PINBUK juga membuat perkiraan akan asset total BMT, yang diperhitungkan telah mencapai $\mathrm{Rp}$ 1,5 triliyun pada tahun 2005 dan Rp 2 triliyun pada tahun 2006.

Pertumbuhan BMT di wilayah Bogor pun semakin meningkat secara signifikan yang terlihat dalam progress data yang ditampilkan oleh Badan Pusat Statistik Kota Bogor yang tertera dalam tabel 1.1 dibawah ini.

Tabel Pertumbuhan BMT Wilayah Bogor

\begin{tabular}{|c|c|c|c|c|c|c|}
\hline \multirow{2}{*}{ Tahun } & \multirow{2}{*}{$\begin{array}{l}\text { Jumlah } \\
\text { Kantor }\end{array}$} & \multirow{2}{*}{$\begin{array}{l}\text { Jumlah } \\
\text { Anggota }\end{array}$} & \multirow{2}{*}{$\begin{array}{c}\text { Jumlah } \\
\text { Karyawan }\end{array}$} & \multicolumn{2}{|c|}{ Modal } & \multirow{2}{*}{ Total Asset } \\
\hline & & & & Sendiri & Luar & \\
\hline 2006 & 6 & 622 & 24 & 59.841 .000 & 15.634 .000 & 234.729 .000 \\
\hline 2007 & 10 & 426 & 82 & 98.900 .300 & 1.264 .191 .820 & 1.363 .092 .120 \\
\hline 2008 & 15 & 724 & 102 & 245.890 .500 & 1.567 .456 .890 & 1.543 .121 .460 \\
\hline 2009 & 17 & 637 & 136 & 486.980 .000 & 2.345 .678 .900 & 2.471 .986 .120 \\
\hline 2010 & 21 & 784 & 152 & 876.130 .000 & 3.456 .870 .000 & 3.876 .510 .000 \\
\hline
\end{tabular}

Sumber: Dinas Perindag Kota Bogor

Terlihat dari data diatas bahwa pertumbuhan BMT wilayah Bogor mengalami pergerakan yang cukup signifikan dimana jumlah kantor BMT mengalami peningkatan dari tahun ke tahun hingga saat ini. Dan pertumbuhannya pun tidak hanya terlihat dari bertambahnya jumlah kantor tapi juga terlihat dari modal yang diperoleh BMT baik dari pihak luar atau yang didapatkan sendiri, serta terlihat dari total asset yang dimiliki oleh BMT itu sendiri.

Konsep operasional penyaluran dana yang diberikan oleh BMT ini yang nantinya akan membantu meningkatkan kesejahteraan masyarakat. Dan hal inilah yang akan penulis teliti, apakah penyaluran dana yang diberikan oleh BMT ini mampu meningkatkan kesejahteraan masyarakat disekitarnya dan juga seperti apakah penyaluran dana tersebut dilakukan. Berdasarkan latar belakang diatas, penulis ingin meneliti tentang, "Pengaruh Penyaluran Dana Baytul Maal wat Tamwil (BMT) terhadap Kesejahteraan Masyarakat Bogor (Periode Tahun 20082011)"

\section{B. Metodologi}

Dalam penelitian ini, penulis menggunakan data primer dari BMT wilayah Bogor yaitu BMT Ibaadurrahman (Ciawi), BMT El-Umma (Ciampea), BMT Wasilah (Merdeka), BMT Al-Ghazaly (Mawar), serta BMT Amalatina (Cimahpar) dan juga mewawancarai langsung masyarakat wilayah Bogor yang merupakan nasabah dari kelima BMT yang telah 
disebutkan sebelumnya dengan cara menyebarkan kuisioner, dimana penulis langsung meneliti dan menganalisis data yang berhubungan dengan BMT untuk mengukur penyaluran dana yang diberikan oleh BMT berpengaruh atau tidak terhadap peningkatan kesejahteraan masyarakat. Data primer adalah data yang dikumpulkan secara langsung oleh peneliti dengan cara observasi, wawancara dan survey lapangan.

Untuk dapat lebih memahami, berikut ini akan diberikan gambaran mengenai konsep yang digunakan dalam penelitian ini, maka berikut diberikan beberapa definisi operasional mengenai konsepkonsep yang berkaitan dengan pengaruh penyaluran dana yang diberikan oleh BMT terhadap peningkatan kesejahteraan masyarakat.

1. Penyaluran Dana BMT, yaitu mekanisme operasional bagaimana dana yang dimiliki oleh BMT disalurkan kepada masyarakat yang bertujuan untuk meningkatkan kesejahteraan masyarakat sekitarnya. Dimana variabel penyaluran dana BMT diwakili oleh variabel pembiayaan mudharabah, pembiayaan musyarakah, pembiayaan murabahah dan pembiayaan $\mathrm{Al}$-Qardh.

a. Pembiayaan mudharabah adalah pembiayaan dengan akad kerjasama usaha antara dua pihak dimana pihak pertama (shahibul maal) menyediakan modal, sedangkan pihak lainnya (mudharib) menjadi pengelolanya dan mengenai keuntungannya disesuaikan dengan kontrak yang ada. ${ }^{2}$

b. Pembiayaan musyarakah adalah pembiayaan dengan akad kerjasama antara dua pihak atau lebih untuk

2 Muhammad Syafi'i Antonio, 2003. Bank Syariah dari Teori ke Praktek. Jakarta: Gema Insani Press, hlm. 95 suatu usaha tertentu dimana masingmasing pihak memberikan kontribusi dana dengan kesepakatan bahwa keuntungan dan resiko akan ditanggung bersama sesuai dengan kesepakatan $^{3}$

c. Pembiayaan murabahah adalah pembiayaan berdasarkan jual beli dimana pihak penyedia dana bertindak selaku penjual dan nasabah selaku pembeli. Harga beli diketahui bersama dan tingkat keuntungan untuk penyedia dana disepakati dimuka. ${ }^{4}$

d. Pembiayaan Al-Qardh adalah perjanjian pembiayaan antara pihak penyedia dana dengan nasabah yang dianggap layak menerima yang diprioritaskan bagi pengusaha kecil pemula yang potensial akan tetapi tidak memiliki modal apapun selain kemampuan berusaha, dimana nasabah hanya diwajibkan mengembalikan pokok pinjaman pada waktu jatuh tempo dan pihak penyedia dana membebani nasabah dengan biaya administrasi saja. ${ }^{5}$

2. Kesejahteraan Masyarakat, yaitu suatu tata kehidupan dan penghidupan sosial, materil maupun spiritual yang diliputi oleh rasa keselamatan, kesusilan dan ketentraman lahir bathin yang memungkinkan tiap warga Negara untuk mengadakan usaha pemenuhan kebutuhannya. Dimana variabel yang mewakili kesejahteraan masyarakat adalah peningkatan pendapatan.

\footnotetext{
Ibid., hlm. 90

A. Azharuddin Latif, 2005. Fiqh Muamalah. Jakarta: UIN Jakarta Press, hlm. 118

5 Karnaen Perwaatmadja dan Antonio, Muh. Syafi'i. 1992. Apa dan Bagaimana Bank Islam. Yogyakarta: Dana Bhakti Wakaf, hlm. 106
} 
a. Peningkatan pendapatan adalah kenaikan kotor dalam asset atau penurunan dalam liabilitas atau gabungan dari keduanya selama periode yang dipilih oleh pernyataan pendapatan yang bertujuan untuk meraih keuntungan. ${ }^{6}$

Jenis dan sumber data yang digunakan dalam penelitian ini adalah data primer dan data sekunder.

1. Data primer didapatkan dari data lapangan yang diamati dari sampel penelitian BMT yang diteliti, terutama yang berkaitan dengan data penyaluran dana BMT dan peningkatan pendapatan masyarakat wilayah Bogor. Data ini didapatkan langsung dari masyarakat wilayah Bogor melalui penyebaran kuisioner dan wawancara untuk meneliti langsung pengaruh penyaluran dana yang diberikan oleh BMT kepada masyarakat.

2. Data sekunder yang menjadi pelengkap data yang diperoleh dari Dinas Koperasi dan UMKM Kota Bogor.

\section{Analisis Regresi Linear Berganda}

Analisis data dilakukan melalui serangkaian tahapan pengujian menggunakan analisis regresi berganda (multiple regression analysis). Regresi linear berganda bertujuan untuk menguji dua atau lebih variabel independen terhadap variabel dependen. Dan pada penelitian ini, regresi linear berganda bertujuan untuk mengetahui pengaruh penyaluran dana yang diberikan oleh BMT terhadap peningkatan kesejahteraan masyarakat wilayah Bogor. Serta mengukur kekuatan hubungan antara variabel dependen dan variabel independen.

6 Muhammad Syafi'i Antonio, 2003. Bank Syariah dari Teori ke Praktek. Jakarta: Gema Insani Press, hlm. 204
Model regresi yang dikembangkan untuk menguji hipotesis-hipotesis yang telah dirumuskan dalam penelitian ini adalah sebagai berikut:

PPM $=\alpha+\beta_{1}$ PMudh $+\beta_{2}$ PMusy $+\beta_{3}$
PMura $+\beta_{4}$ PQard $+\varepsilon_{i}$

Keterangan:

PPM = Peningkatan Pendapatan

$\alpha \quad=$ konstanta

$\beta_{1,2,3,4}=$ koefisien variabel

PMusy = Pembiayaan Musyarakah

PMudh = Pembiayaan Mudharabah

PMura = Pembiayaan Murabahah

PQard = Pembiayaan Al-Qardh

$\varepsilon_{\mathrm{i}} \quad=$ residual error

Sebelum dilakukan pengujian regresi linear berganda, terlebih dahulu dilakukan uji asumi klasik agar memperoleh hasil estimasi yang terbaik berdasarkan asumi BLUE (dimana B = Best, $\mathrm{L}=$ Linear, $\mathrm{U}=$ Unbiased, $\mathrm{E}=$ Estimasion), sehingga memenuhi asumsi dasar klasik, yaitu:

a. Tidak adanya Multikolonieritas diantara variabel yang dijelaskan.

b. Tidak terjadi Heterokedastisitas.

c. Tidak adanya Autokorelasi.

d. Data yang digunakan dalam penelitian ini berdistribusi normal.

Dalam penelitian ini, uji asumsi klasik yang digunakan adalah sebagai berikut:

\section{a. Uji Normalitas.}

Uji normalitas dilakukan bertujuan untuk menguji apakah dalam model regresi variabel dependen, variabel independen, atau bahkan keduanya memiliki distribusi normal atau tidak. Model regresi yang baik adalah memiliki distribusi data yang normal atau mendekati normal. Menurut 
Ghozali, ${ }^{7}$ uji normalitas dapat dideteksi dengan melihat penyebaran data (titik) pada sumbu diagonal dari grafik atau dengan melihat garis histogram dari residualnya. Dasar pengambilan kepuusan dalam uji normalitas (Anita Dwi Lestari, 2010: 84) adalah sebagai berikut:

1) Jika data menyebar disekitar garis diagonal dan mengikuti arah garis diagonal atau grafik histogramnya menunjukan pola distribusi normal, maka model regresi memenuhi asumsi normalitas.

2) Jika data menyebar jauh dari garis diagonal dan atau tidak mengikuti arah garis diagonal atau grafik histogramnya tidak menunjukan ditrsibusi pola normal, maka model regresi tidak memenuhi asumsi normalitas.

\section{b. Uji Multikolonieritas.}

Uji multikolonieritas dilakukan bertujua untuk menguji apakah dalam persamaan regresi ditemukan adanya korelasi antar variabel bebas (independen). Model regresi yang baik seharusnya tidak terjadi korelasi diantara variabel independen. Untuk mengetahui ada atau tidaknya multikolonieritas dapat dilihat dari nilai tolerance dan Variance Inflation Faktor (VIF). Apabila tolerance mendekati 1 atau nilai VIF disekitar angka 1, maka tidak terjadi multikolonieritas.

\section{c. Uji Autokorelasi.}

Uji autokorelasi dilakukan untuk mengetahui adanya korelasi antar pengganggu (error term) pada suatu periode dengan kesalahan pada periode sebelumnya yang biasanya terjadi karena menggunakan data time series. Model regresi yang baik adalah yang bebas dari autokorelasi. Untuk mendeteksi ada atau tidaknya autokorelasi dapat dilakukan dengan uji Durbin-Watson, dimana hipotesis yang diuji adalah:

$\mathrm{H} 0$ : tidak ada autokorelasi $(\mathrm{r}=0)$

Ha : ada autokorelasi $(\mathrm{r}=0)$

Pengambilan keputuasan ada atau tidaknya autokorelasi (Anita Dwi Lestari, 2010: 86) adalah sebagai berikut:

1) Bila nilai Durbin-Watson dibawah -2, maka ada autokorelasi positif.

2) Bila nilai Durbin-Watson diantara -2 sampai +2, maka tidak ada autokorelasi.

3) Bila nilai Durbin-Watson diatas +2 , maka ada autokorelasi negatif.

\section{d. Uji Heterokedastisitas.}

Uji heretokedastisitas dilakukan bertujuan untuk menguji apakah dalam model regresi terjadi ketidaksamaan varians dari residual satu pengamatan ke pengamatan lainnya. Menurut Santoso $^{8}$ deteksi adanya heterokedastisitas adalah:

1) Nilai probabilitas $>0.05$, berarti bebas dari heterokedastisitas.

2) Nilai probabilitas $<0.05$, berarti terkena heterokedastisitas.

\section{b. Uji Hipotesis}

Pengujian hipotesis ini dilakukan melalui dua (2) tahapan, yaitu: pengujian hipotesis pertama dengan menggunakan uji adjusted $\mathrm{R}^{2}$ (koefisien determinasi), uji $\mathrm{F}$ dan uji $\mathrm{t}$ dan merangking standardized coefficients beta yang diperoleh dari hasil analisis regresi linear berganda.
7 Imam Ghozali, 2006. Aplikasi Analisis Multivariate dengan Program SPSS. Edisi ke-3. Semarang: Badan Penerbit Universitas Diponegoro, hlm. 76
8 Singgih Santoso, 2002. Buku Latihan SPSS Statistik Non Parametik. Jakarta: Penerbit PT Elex Media Komputindo Kelompok Gramedia, hlm. 301 
Pengujian hipotesis pertama yang diajukan pada penelitian ini yaitu diduga adanya pengaruh signifikan dan positif antara penyaluran dana BMT terhadap peningkatan kesejahteraan masyarakat wilayah Bogor, dapat dilakukan dengan tiga (3) cara, yaitu:

1) Uji koefisien determinasi $\left(R^{2}\right)$

Untuk mengetahui seberapa besar variabel independen dapat menjelaskan variabel dependen, maka perlu diketahui nilai koefisien determinasi (adjusted $R$ squared). Jika adjusted $R$ squared adalah sebesar 1 maka fluktuasi variabel dependen seluruhnya dapat dijelaskan oleh variabel independen dan tidak ada faktor lain yang menyebabkan fluktuasi variabel. Nilai adjusted $R$ squared berkisar hampir 1, maka semakin kuat kemampuan variabel independen dapat menjelaskan variabel dependen. Sebaliknya, jika nilai adjusted $R$ squared semakin mendekati nilai 0 , maka semakin lemah kemampuan variabel independen dapat menjelaskan variabel dependen.

2) Pengujian secara parsial (Uji t)

Uji hipotesis dengan "uji t" yaitu dengan mencari "t hitung" dan membandingkannya dengan "t tabel", apakah variabel independent secara parsial memiliki pengaruh yang signifikan atau tidak dengan variabel dependent.

Formula hipotesis:

$\mathrm{H}_{0}: \beta=0$, maka variabel $\mathrm{X}$ secara parsial tidak berpengaruh signifikan terhadap variabel Y.

$\mathrm{H}_{1}: \beta \mathrm{e} \neq 0$, maka variabel $\mathrm{X}$ secara parsial ber- pengaruh signifikan terhadap variabel $Y$.

Dasar pengambilan keputusannya adalah:

1) Jika $t_{\text {hitung }}<t_{\text {tabel}}$, maka $\mathrm{H}_{1}$ diterima.

Jika $t_{\text {hitung }}>t_{\text {tabel}}$, maka $\mathrm{H}_{1}$ ditolak.

2) Berdasarkan (signifikan) dasar pengambilan keputusan adalah:

Jika signifikan $>0.05$, maka $\mathrm{H}_{1}$ diterima.

Jika signifikan $<0.05$, maka $\mathrm{H}_{1}$ ditolak.

3) Uji menyeluruh/simultan (Uji F)

Untuk mengetahui ada tidaknya pengaruh secara bersama-sama variabel bebas terhadap variabel terikatnya dilakukan uji F.

Formula hipotesis:

$$
\begin{aligned}
\mathrm{H} 0: \beta_{1}-\beta_{4}=0, & \text { maka variabel } \\
& \text { bebas }(\mathrm{X}) \text { secara } \\
& \text { simultan tidak } \\
& \text { berpengaruh } \\
& \text { terhadap variabel } \\
& \text { terikat }(\mathrm{Y}) .
\end{aligned}
$$

Dasar pengambilan keputusan adalah:

1) Jika $F_{\text {hitung }}<F_{\text {tabel, }}$ maka $\mathrm{H}_{1}$ ditolak.

Jika $\mathrm{F}_{\text {hitung }}>\mathrm{F}_{\text {tabel, }}$ maka $\mathrm{H}_{1}$ diterima.

2) Berdasarkan (signifikan) dasar pengambilan keputusan adalah:

Jika signifikan $>0.05$, maka $\mathrm{H}_{1}$ diterima.

Jika signifikan $<0.05$, maka $\mathrm{H}_{1}$ ditolak.

\section{Hasil dan Pembahasan}

Dalam bab ini dilakukan pembahasan mengenai pengaruh penyaluran dana Baitul Maal Wattamwil (BMT) terhadap peningkatan kesejahteraan masyarakat wilayah Bogor. Analisis ini ditujukan untuk mengetahui pengaruh variabel independen terhadap variabel dependen. Adapun variabel independennya adalah sebagai berikut pembiayaan mudharabah, 
pembiayaan musyarakah, pembiayaan murabahah dan pembiayaan al-qardh, sedangkan variabel dependennya adalah peningkatan pendapatan masyarakat.

\section{Uji Regresi Linear Berganda}

Di bawah ini merupakan hasil uji regresi linear berganda antara variabel dependen (Y) dengan Variabel independen
$\left(\mathrm{X}_{1,2,3,4}\right)$ yang tertera pada tabel 4.7. Variabel dependen (Y) yang dimaksud adalah variabel peningkatan pendapatan masyarakat (PPM), sedangkan variabel independen $\left(\mathrm{X}_{1,2,3,4}\right)$ yang dimaksud adalah variabel pembiayaan mudharabah (PMudh), variabel pembiayaan musyarakah (PMusy), variabel pembiayaan murabahah (PMura), dan variabel pembiayaan al-qardh (PQard).

Tabel Hasil Pengolahan Data Regresi Linear Berganda

Variables Entered/Removed (b)

\begin{tabular}{|c|l|c|c|}
\hline Model & \multicolumn{1}{|c|}{ Variables Entered } & $\begin{array}{c}\text { Variables } \\
\text { Removed }\end{array}$ & Method \\
\hline 1 & $\begin{array}{l}\text { Pembiayaan Al-Qardh, Pembiayaan } \\
\text { Musyarakah, Pembiayaan Mudharabah, } \\
\text { Pembiayaan Murabahah (a) }\end{array}$ & Enter \\
\hline
\end{tabular}

a. All requested variables entered.

b. Dependent Variable: Peningkatan Pendapatan Masyarakat

Model Summary

\begin{tabular}{|l|c|c|c|c|}
\hline Model & R & R Square & $\begin{array}{c}\text { Adjusted R } \\
\text { Square }\end{array}$ & $\begin{array}{c}\text { Std. Error of the } \\
\text { Estimate }\end{array}$ \\
\hline 1 & $0,592(\mathrm{a})$ & 0,351 & 0,323 & 1,29881 \\
\hline
\end{tabular}

a. Predictors: (Constant), Pembiayaan Al-Qardh, Pembiayaan Musyarakah, Pembiayaan Mudharabah, Pembiayaan Murabahah

ANOVA (b)

\begin{tabular}{|ll|r|r|r|r|c|}
\hline & Model & \multicolumn{1}{c|}{$\begin{array}{c}\text { Sum of } \\
\text { Squares }\end{array}$} & df & $\begin{array}{c}\text { Mean } \\
\text { Square }\end{array}$ & F & Sig. \\
\hline 1 & Regression & 86,494 & 4 & 21,623 & 12,818 & $0,000(\mathrm{a})$ \\
& Residual & 160,256 & 95 & 1,687 & & \\
& Total & 246,750 & 99 & & & \\
\hline
\end{tabular}

a. Predictors: (Constant), Pembiayaan Al-Qardh, Pembiayaan Musyarakah, Pembiayaan Mudharabah, Pembiayaan Murabahah

b. Dependent Variable: Peningkatan Pendapatan Masyarakat

Coefficients(a)

\begin{tabular}{|c|c|c|c|c|c|c|}
\hline & \multirow{2}{*}{ Model } & \multicolumn{2}{|c|}{$\begin{array}{l}\text { Unstandardized } \\
\text { Coefficients }\end{array}$} & \multirow{2}{*}{$\begin{array}{c}\begin{array}{c}\text { Standardized } \\
\text { Coefficients }\end{array} \\
\text { Beta }\end{array}$} & \multirow{2}{*}{$\begin{array}{l}\mathbf{t} \\
\mathrm{B}\end{array}$} & \multirow{2}{*}{$\begin{array}{l}\text { Sig. } \\
\text { Std. } \\
\text { Error }\end{array}$} \\
\hline & & B & $\begin{array}{l}\text { Std. } \\
\text { Error }\end{array}$ & & & \\
\hline \multirow[t]{5}{*}{1} & (Constant) & 27,457 & 3,794 & & 7,236 & 0,000 \\
\hline & $\begin{array}{l}\text { Pembiayaan } \\
\text { Mudharabah }\end{array}$ & 0,134 & 0,178 & 0,079 & 0,755 & 0,002 \\
\hline & $\begin{array}{l}\text { Pembiayaan } \\
\text { Musyarakah }\end{array}$ & 0,875 & 0,145 & 0,563 & 6,051 & 0,000 \\
\hline & Pembiayaan Murabahah & 0,243 & 0,197 & 0,139 & 0,232 & 0,001 \\
\hline & Pembiayaan Al-Qardh & 0,134 & 0,159 & 0,106 & 0,842 & 0,002 \\
\hline
\end{tabular}

a. Dependent Variable: Peningkatan Pendapatan Masyarakat 
Berdasarkan pada tabel di atas bagian Coefficients, maka dapat diperoleh model regresi linear berganda dengan persamaan sebagai berikut:

$Y=27,457+0,134 X_{1}+0,875 X_{2}+$
$0,243 X_{3}+0,134 X_{4}+\varepsilon$

Keterangan:

$\mathrm{Y}=$ Peningkatan Pendapatan Masyarakat (PPM)

$\mathrm{X} 1=$ Pembiayaan Mudharabah (PMudh)

$\mathrm{X} 2$ = Pembiayaan Musyarakah (PMusy)

$\mathrm{X} 3=$ Pembiayaan Murabahah (PMura)

$\mathrm{X} 4=$ Pembiayaan Al-Qardh (PQard)

Nilai masing-masing koefisien regresi variabel independen dari model regresi tersebut memberi gambaran bahwa:

a. Koefisien regresi variabel Pembiayaan Mudharabah (X1) sebesar 0,134 menggambarkan bahwa pembiayaan mudharabah mempunyai pengaruh positif terhadap besarnya peningkatan pendapatan masyarakat, yang artinya semakin besarnya pembiayaan mudharabah maka peningkatan pendapatan masyarakat wilayah Bogor akan semakin besar oleh karena itu, pembiayaan mudharabah memiliki pengaruh yang positif terhadap peningkatan pendapatan masyarakat, ketika pembiayaan mudharabah naik sebesar 1 rupiah akan berdampak pada bertambahnya peningkatan pendapatan masyarakat sebesar 0,134 rupiah.

b. Koefisien regresi variabel Pembiayaan Musyarakah (X2) sebesar 0,875 menggambarkan bahwa pembiayaan musyarakah mempunyai pengaruh positif terhadap besarnya peningkatan pendapatan masyarakat, yang artinya semakin besarnya pembiayaan musyarakah maka peningkatan pendapatan masyarakat wilayah Bogor akan semakin besar oleh karena itu, pembiayaan musyarakah memiliki pengaruh yang positif terhadap peningkatan pendapatan masyarakat, ketika pembiayaan musyarakah naik sebesar 1 rupiah akan berdampak pada bertambahnya peningkatan pendapatan masyarakat sebesar 0,875 rupiah.

c. Koefisien regresi variabel Pembiayaan Murabahah (X3) sebesar 0,243 menggambarkan bahwa pembiayaan murabahah mempunyai pengaruh positif terhadap besarnya peningkatan pendapatan masyarakat, yang artinya semakin besarnya pembiayaan murabahah maka peningkatan pendapatan masyarakat wilayah Bogor akan semakin besar oleh karena itu, pembiayaan murabahah memiliki pengaruh yang positif terhadap peningkatan pendapatan masyarakat, ketika pembiayaan murabahah naik sebesar 1 rupiah akan berdampak pada bertambahnya peningkatan pendapatan masyarakat sebesar 0,243 rupiah.

d. Koefisien regresi variabel Pembiayaan Al-Qardh (X4) sebesar $\quad 0,134$ menggambarkan bahwa pembiayaan alqardh mempunyai pengaruh positif terhadap besarnya peningkatan pendapatan masyarakat, yang artinya semakin besarnya pembiayaan al-qardh maka peningkatan pendapatan masyarakat wilayah Bogor semakin besar oleh karena itu, pembiayaan alqardh memiliki pengaruh yang positif terhadap peningkatan pendapatan masyarakat, ketika pembiayaan al-qardh naik sebesar 1 rupiah akan berdampak pada bertambahnya peningkatan pendapatan masyarakat sebesar 0,134 rupiah. 


\section{Uji Hipotesis Parsial (Uji T)}

Uji hipotesis secara parsial digunakan untuk mengetahui pengaruh dari masingmasing variabel independen terhadap variabel dependen. Uji ini dilakukan dengan cara amembandingkan nilai $T$ hitung dengan nilai $\mathrm{T}$ tabel. Hipotesis statistik yang diajukan untuk uji $\mathrm{T}$ adalah sebagai berikut:

$$
\begin{aligned}
\mathrm{H} 0: & \mathrm{b}_{1}=0 \\
\mathrm{H} 1: & \mathrm{b}_{1} \neq 0 \\
& \mathrm{~b}_{2}=0 \\
& \mathrm{~b}_{2} \neq 0 \\
& \mathrm{~b}_{3}=0 \\
& \mathrm{~b}_{3} \neq 0 \\
& \mathrm{~b}_{4}=0 \\
& \mathrm{~b}_{4} \neq 0
\end{aligned}
$$

Untuk memperoleh nilai $\mathrm{T}$ tabel, dapat dilihat pada tabel $\mathrm{T}$, yaitu pada degrees of freedom (df) sebesar 96 dan $1 / 2 \alpha$ $=5 \%$, maka nilai $\mathrm{T}$ tabel sebesar $\pm 0,200$

Dengan membandingkan nilai $\mathrm{T}$ hitung dengan $\mathrm{T}$ tabel, maka dapat disimpulkan bahwa :

a. Variabel Pembiayaan Mudharabah yaitu $\mathrm{t}$ hitung $>\mathrm{t}$ tabel atau 0,755 $>0,200$ maka $\mathrm{H} 0$ ditolak dan hipotesis penelitian diterima, yang artinya pembiayaan mudharabah mempunyai pengaruh signifikan terhadap peningkatan pendapatan masyarakat wilayah Bogor.

b. Variabel Pembiayaan Musyarakah yaitu $\mathrm{t}$ hitung $>\mathrm{t}$ tabel atau 6,051 >0,200 maka $\mathrm{H} 0$ ditolak dan hipotesis penelitian diterima, yang artinya pembiayaan musyarakah mempunyai pengaruh signifikan terhadap peningkatan pendapatan masyarakat wilayah Bogor.

c. Variabel Pembiayaan Murabahah yaitu $t$ hitung $>\mathrm{t}$ tabel atau 1,232 >0,200 maka $\mathrm{H} 0$ ditolak dan hipotesis penelitian diterima, yang artinya pembiayaan murabahah mempunyai pengaruh signifikan terhadap peningkatan pendapatan masyarakat wilayah Bogor.

d. Variabel Pembiayaan Al-Qardh yaitu $t$ hitung $>\mathrm{t}$ tabel atau 0,842 $>0,200$ maka H0 ditolak dan hipotesis penelitian diterima, yang artinya pembiayaan alqardh mempunyai pengaruh signifikan terhadap peningkatan pendapatan masyarakat wilayah Bogor.

Langkah pengujian hipotesis dilakukan jika dalam pengolahan datan penelitian sudah menyiapkan $\mathrm{t}$ tabel, namun jika tabel tersebut tidak tersedia maka untuk memutuskan menerima atau menolak hipotesis penelitian dapat dilakukan dengan melihat nilai signifikansi (Sig.) pada tabel 4.7 bagian Coefficients, yaitu masingmasing variabel independen mempunyai nilai Sig. Di bawah $10 \%$ atau 0,100 . Variabel Pembiayaan Mudharabah (X1) nilai Sig.nya sebesar 0,002; Variabel Pembiayaan Musyarakah (X2) nilai Sig.nya sebesar 0,000; Variabel Pembiayaan Murabahah (X3) nilai Sig.nya sebesar 0,001; Variabel Pembiayaan Al-Qardh (X4) nilai Sig.nya sebesar 0,002 . Dengan demikian dapat disimpulkan bahwa Variabel Pembiayaan Mudharabah (X1), Variabel Pembiayaan Musyarakah (X2), Variabel Pembiayaan Murabahah (X3), Variabel Pembiayaan Al-Qardh (X4) secara parsial mempunyai pengaruh signifikan terhadap Variabel Peningkatan Pendapatan Masyarakat (Y).

\section{Uji Hipotesis Serempak (Uji F)}

Uji hipotesis secara serempak digunakan untuk mengetahui pengaruh dari variabel independen secara keseluruhan terhadap variabel dependen. Uji ini dilakukan dengan membandingkan nilai $\mathrm{F}$ hitung dengan nilai $F$ tabel. Nilai $F$ hitung dapat dilihat pada tabel 4.13 bagian Anova. 
Uji hipotesis statistik yang diajukan untuk uji $\mathrm{F}$ adalah sebagai berikut:
$\mathrm{H} 0$

$\mathrm{H} 1$

$$
\begin{aligned}
& : \mathrm{b} 1=\mathrm{b} 2=\mathrm{b} 3=\mathrm{b} 4=0 \\
& : \mathrm{b} 1 \neq \mathrm{b} 2 \neq \mathrm{b} 3 \neq b 4 \neq 0
\end{aligned}
$$

Tabel ANOVA

\begin{tabular}{|rl|r|r|r|r|r|}
\hline Model & \multicolumn{1}{c|}{$\begin{array}{c}\text { Sum of } \\
\text { Squares }\end{array}$} & df & \multicolumn{1}{c|}{$\begin{array}{c}\text { Mean } \\
\text { Square }\end{array}$} & F & Sig. \\
\hline 1 & Regression & 246,750 & 5 & 49,350 & 19.647 & 0.000 \\
& Residual & 0,000 & 94 & 0,000 & & \\
& Total & 246,750 & 99 & & & \\
\hline
\end{tabular}

a. Predictors: (Constant), Pembiayaan Murabahah, Pembiayaan Musyarakah, Pembiayaan Mudharabah, Pembiayaan Al-Qardh

b. Dependent Variable: Peningkatan Pendapatan Masyarakat

Dari hasil uji-F diperoleh nilai probabilitas $(0.000)<$ alpha $(0,05)$ maka tolak $\mathrm{H} 0$ yang berarti model signifikan atau minimal ada satu peubah $X$ yang berpengaruh nyata terhadap Y.

\section{Koefisien Determinasi (R-Square)}

Nilai $\mathrm{R}^{2}$ atau $\mathrm{R}$-square dapat dilihat pada tabel 4.1 bagian Model Summary. Hasil pengolahan data menunjukkan bahwa nilai $\mathrm{R}^{2}$ sebesar 0,351. Nilai tersebut menggambarkan bahwa besarnya variabel independen (Variabel Pembiayaan Mudharabah, Variabel Pembiayaan Musyarakah, Variabel Pembiayaan Murabahah, dan Variabel Pembiayaan AlQardh) terhadap naik turunnya atau variasi variabel dependen (Variabel Peningkatan Pendapatan Masyarakat) adalah sebesar $35,1 \%$ dan sisanya sebesar $64,9 \%$ merupakan sumbangan dari variabel lain yang tidak dimasukan kedalam model yang diajukan dalam penelitian ini (terkumpul dalam variabel error $/ \varepsilon$ ). Sedangkan, untuk nilai $\mathrm{R}$ sebesar 0,592 atau $59,2 \%$ berarti hubungan antara variabel independen dengan variabel dependen dalam penelitian ini dapat dikatakan mempunyai hubungan yang cukup kuat karena cukup mendekati $100 \%$.

\section{Uji Asumsi Klasik}

\section{a. Uji Autokorelasi}

Uji korelasi digunakan untuk menguji apakah dalam model regresi linear terdapat korelasi antara kesalahan pengganggu pada periode $\mathrm{t}$ dengan kesalahan pada periode $\mathrm{t}-1$ (sebelumnya). Untuk menguji autokorelasi dapat dilihat dari nilai Durbin Watson (DW), yaitu jika nilai DW terletak antara $d_{u}$ dan $\left(4-d_{u}\right)$ atau $d u \leq D W \leq(4-d u)$ berarti bebas dari autokorelasi, sebaliknya jika nilai $\mathrm{DW}<\mathrm{dL}$ atau $\mathrm{DW}>(4-\mathrm{dL})$ berarti terdapat autokorelasi. Nilai dL; du; $\alpha ; n$; (k - 1). Keterangan: $\mathrm{n}$ adalah jumlah sampel, $\mathrm{k}$ adalah jumlah variabel, dan $\alpha$ adalah taraf signifikan.

Dari table Durbin-Watson:

\begin{tabular}{|c|c|}
\hline Alpha $=\mathbf{5 \%}$ & $\mathbf{D W}=\mathbf{1 , 6 8 8}$ \\
\hline $\mathrm{K}=4$ & $4-\mathrm{du}=2,5$ \\
\hline $\mathrm{N}=100$ & $4-\mathrm{dL}=2.3$ \\
\hline $\mathrm{dL}=1.7$ & \\
\hline $\mathrm{du}=1.7$ & \\
\hline
\end{tabular}

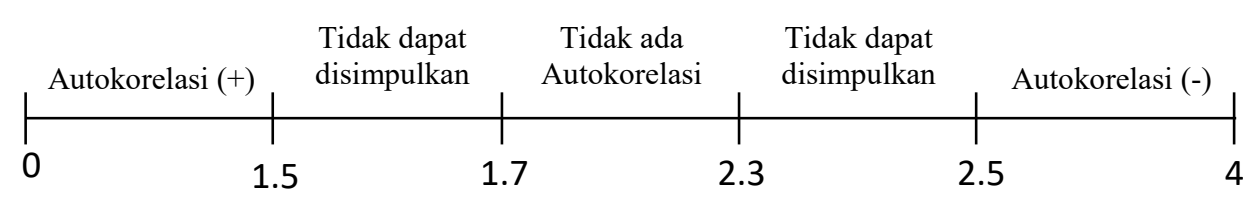


Berdasarkan hasil uji diatas dapat disimpulkan bahwa nilai DW jatuh diwilayah "tidak dapat disimpulkan ", karena nilai $\mathrm{DW}=1,688$ dekat dengan Tidak ada autokorelasi maka dapat dikatakan tidak terdapat autokorelasi pada model regresi.

\section{b. Uji Multikolinearitas}

Uji multikolinearitas digunakan untuk mengetahui apakah terjadi korelasi yang kuat diantara variabel-variabel independen yang diikutsertakan dalam pembentukan model. Untuk mendeteksi apakah model regresi linear mengalami multikolinearitas dapat diperiksa menggunakan Varianve Inflation Factor (VIF) untuk masingmasing variabel independen yaitu jika suatu variabel independen mempunyai nilai VIF $>10$, maka berarti telah terjadi multikolinearitas.

Tabel Hasil Pengolahan Data untuk Uji Multikolinearitas Coefficients (a)

\begin{tabular}{|c|l|r|r|}
\hline \multicolumn{2}{|c|}{ Model } & \multicolumn{2}{c|}{ Collinearity Statistics } \\
\cline { 3 - 4 } & \multicolumn{2}{|c|}{ Tolerance } & \multicolumn{1}{c|}{ VIF } \\
\hline 1 & $\begin{array}{l}\text { Pembiayaan } \\
\text { Mudharabah }\end{array}$ & 0,620 & 1,612 \\
\hline \multirow{2}{*}{} & $\begin{array}{l}\text { Pembiayaan } \\
\text { Musyarakah }\end{array}$ & 0,790 & 1,266 \\
\hline & Pembiayaan Murabahah & 0,535 & 1,868 \\
\hline & Pembiayaan Al-Qardh & 0,432 & 2,314 \\
\hline
\end{tabular}

a. Dependent Variable: Peningkatan Pendapatan Masyarakat

Coefficient Correlations(a)

\begin{tabular}{|l|l|r|r|r|r|}
\hline \multicolumn{2}{|c|}{ Model } & $\begin{array}{c}\text { Pembiayaan } \\
\text { Al-Qardh }\end{array}$ & $\begin{array}{c}\text { Pembiayaan } \\
\text { Musyarakah }\end{array}$ & $\begin{array}{c}\text { Pembiayaan } \\
\text { Mudharabah }\end{array}$ & $\begin{array}{c}\text { Pembiayaan } \\
\text { Murabahah }\end{array}$ \\
\hline Correlations & $\begin{array}{l}\text { Pembiayaan } \\
\text { Al-Qardh }\end{array}$ & 1,000 &,- 180 &,- 455 &,- 626 \\
\hline & $\begin{array}{l}\text { Pembiayaan } \\
\text { Musyarakah }\end{array}$ &,- 180 & 1,000 &, 440 &,- 080 \\
\hline & $\begin{array}{l}\text { Pembiayaan } \\
\text { Mudharabah }\end{array}$ &,- 455 &, 440 & 1,000 &, 062 \\
\hline & $\begin{array}{l}\text { Pembiayaan } \\
\text { Murabahah }\end{array}$ &,- 626 &,- 080 &, 062 & 1,000 \\
\hline Covariances & $\begin{array}{l}\text { Pembiayaan } \\
\text { Al-Qardh }\end{array}$ &, 025 &,- 004 &,- 013 &,- 020 \\
\hline & $\begin{array}{l}\text { Pembiayaan } \\
\text { Musyarakah }\end{array}$ &,- 004 &, 021 &, 011 &,- 002 \\
\hline & $\begin{array}{l}\text { Pembiayaan } \\
\text { Mudharabah }\end{array}$ &,- 013 &, 011 &, 032 &, 002 \\
\hline & $\begin{array}{l}\text { Pembiayaan } \\
\text { Murabahah }\end{array}$ &,- 020 &,- 002 &, 002 &, 039 \\
\hline
\end{tabular}

a. Dependent Variable: Peningkatan Pendapatan Masyarakat

Berdasarkan hasil pengolahan data pada tabel 4.3 bagian Coefficients diketahui bahwa nilai VIF dari masing-masing variabel independen lebih kecil daripada 5, yaitu nilai VIF variabel Pembiayaan Mudharabah sebesar 1,612; nilai VIF 
variabel Pembiayaan Musyarakah sebesar 1,266; nilai VIF variabel Pembiayaan Murabahah sebesar 1,868; dan nilai VIF variabel Pembiayaan Al-Qardh sebesar 2,314. Sedangkan, pada bagian Coefficients Correlations dapat dilihat bahwa nilai korelasi diantara variabel independen dapat dikatakan mempunyai korelasi yang lemah. Dengan demikian, dapat disimpulkan bahwa diantara variabel independen tersebut tidak ada korelasi atau tidak terjadi multikolinearitas pada model regresi.

\section{c. Uji Normalitas}

Uji normalitas dilakukan bertujuan untuk menguji apakah dalam model regresi, variable pengganggu atau residual memiliki distribusi normal atau tidak. Uji normalitas menghasilkan grafik normal probability plot yang tampak gambar 4.5 dan tabel 4.16 di bawah ini.

Uji Normalitas dengan Gambar P-P Plot

\section{Normal P-P Plot of Regression Standardized Residual}

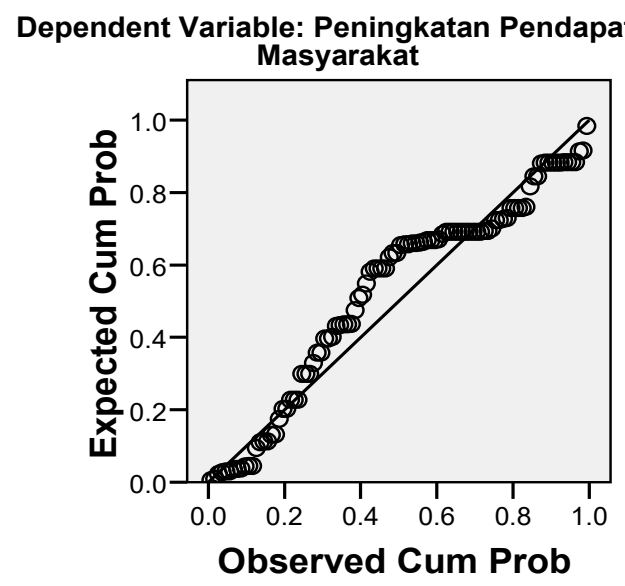

Tabel 4.15 Uji Normalitas dengan One Sample Kolmogorov One-Sample Kolmogorov-Smirnov Test

\begin{tabular}{|c|c|c|c|c|c|c|c|}
\hline & & $\begin{array}{c}\text { Pembiayaan } \\
\text { Mudharabah }\end{array}$ & $\begin{array}{l}\text { Pembiayaan } \\
\text { Musyarakah }\end{array}$ & $\begin{array}{l}\text { Pembiayaan } \\
\text { Murabahah }\end{array}$ & $\begin{array}{l}\text { Pembiayaa } \\
\text { n Al-Qardh }\end{array}$ & $\begin{array}{l}\text { Peningkatan } \\
\text { Pendapatan } \\
\text { Masyarakat }\end{array}$ & residual \\
\hline \multicolumn{2}{|l|}{$\mathrm{N}$} & 100 & 100 & 100 & 100 & 100 & 100 \\
\hline \multirow[t]{2}{*}{$\begin{array}{l}\text { Normal Parameters } \\
(\mathrm{a}, \mathrm{b})\end{array}$} & Mean & 13,1400 & 13,4000 & 17,4600 & 13,3400 & 19,9500 & 0020 \\
\hline & $\begin{array}{l}\text { Std. } \\
\text { Deviation }\end{array}$ & ,93225 & 1,01504 & ,90364 & 1,24900 & 1,57874 & 1,27230 \\
\hline \multirow{3}{*}{$\begin{array}{l}\text { Most Extreme } \\
\text { Differences }\end{array}$} & Absolute &, 270 & ,237 &, 255 & ,217 &, 157 &, 164 \\
\hline & Positive & ,270 & 193 &, 255 & ,217 & ,123 & ,081 \\
\hline & Negative &,- 210 &,- 237 &,- 175 &,- 183 &,- 157 &,- 164 \\
\hline \multicolumn{2}{|c|}{ Kolmogorov-Smirnov Z } & 2,697 & 2,368 & 2,546 & 2,173 & 1,570 & 1,637 \\
\hline \multicolumn{2}{|l|}{ Asymp. Sig. (2-tailed) } &, 000 &, 000 &, 000 &, 000 & 014 & 009 \\
\hline
\end{tabular}

a. Test distribution is Normal

b. Calculated from data

\section{d. Uji Heterokedastisitas}

Uji heterokedastisitas digunakan untuk menguji apakah dalam model regresi linear terdapat kesalahan pengganggu $(\varepsilon)$ mempunyai varians yang sama atau tidak dari satu pengamatan ke pengamatan yang lain. Untuk menguji heterokedastisitas dapat diketahui dari nilai signifikan korelasi Rank Spearman antara masingmasing variabel independen dengan residualnya. Jika nilai signifikan lebih besar dari $\alpha$ (5\%), maka tidak terdapat heterokedastisitas, dan sebaliknya jika lebih kecil dari $\alpha(5 \%)$, maka model terdapat heterokedastisitas. 
Tabel Hasil Pengolahan Data untuk Uji Heterokedastisitas

Correlation

\begin{tabular}{|c|c|c|c|c|c|c|c|}
\hline \multicolumn{2}{|c|}{ Spearman's rho } & \multirow{2}{*}{$\begin{array}{r}\text { Pembiayaan } \\
\text { Mudharabah } \\
1,000\end{array}$} & \multirow{2}{*}{$\begin{array}{r}\text { Pembiayaan } \\
\text { Musyarakah } \\
-379(* *)\end{array}$} & \multirow{2}{*}{$\begin{array}{r}\text { Pembiayaan } \\
\text { Murabahah } \\
243^{*}\end{array}$} & \multirow{2}{*}{$\begin{array}{r}\text { Pembiayaan } \\
\text { Al-Qardh } \\
453 * *\end{array}$} & \multirow{2}{*}{$\begin{array}{r}\text { Peningkatan } \\
\text { Pendapatan } \\
\text { Masyarakat } \\
288 * * \\
\end{array}$} & \multirow{2}{*}{$\begin{array}{r}\text { residual } \\
-028\end{array}$} \\
\hline $\begin{array}{l}\text { Pembiayaan } \\
\text { Mudharabah }\end{array}$ & $\begin{array}{l}\text { Correlation } \\
\text { Coefficient }\end{array}$ & & & & & & \\
\hline & Sig. (2-tailed) & & 000 & 015 & 000 & 004 & 779 \\
\hline & $\mathrm{N}$ & 100 & 100 & 100 & 100 & 100 & 100 \\
\hline \multirow[t]{3}{*}{$\begin{array}{l}\text { Pembiayaan } \\
\text { Musyarakah }\end{array}$} & $\begin{array}{l}\text { Correlation } \\
\text { Coefficient } \\
\end{array}$ & $-379 * *$ & 1,000 & 104 & 089 & $-560 * *$ & 031 \\
\hline & Sig. (2-tailed) & 000 & & 302 & 377 & 000 & 761 \\
\hline & $\mathrm{N}$ & 100 & 100 & 100 & 100 & 100 & 100 \\
\hline \multirow[t]{3}{*}{$\begin{array}{l}\text { Pembiayaan } \\
\text { Murabahah }\end{array}$} & $\begin{array}{l}\text { Correlation } \\
\text { Coefficient }\end{array}$ & $243 *$ & 104 & 1,000 & $694 * *$ & 061 & 058 \\
\hline & Sig. (2-tailed) & 015 & 302 & & 000 & 545 & 566 \\
\hline & $\mathrm{N}$ & 100 & 100 & 100 & 100 & 100 & 100 \\
\hline \multirow[t]{3}{*}{$\begin{array}{l}\text { Pembiayaan } \\
\text { Al-Qardh }\end{array}$} & $\begin{array}{l}\text { Correlation } \\
\text { Coefficient }\end{array}$ & $453 * *$ & 089 & $694 * *$ & 1,000 & 015 & -036 \\
\hline & Sig. (2-tailed) & 000 & 377 & 000 & & 879 & 722 \\
\hline & $\mathrm{N}$ & 100 & 100 & 100 & 100 & 100 & 100 \\
\hline \multirow{3}{*}{$\begin{array}{l}\text { Peningkatan } \\
\text { Pendapatan } \\
\text { Masyarakat }\end{array}$} & $\begin{array}{l}\text { Correlation } \\
\text { Coefficient }\end{array}$ & $288 * *$ & $-560(* *)$ & 061 & 015 & 1,000 & $733 * *$ \\
\hline & Sig. (2-tailed) & 004 & 000 & 545 & 879 & &, 000 \\
\hline & $\mathrm{N}$ & 100 & 100 & 100 & 100 & 100 & 100 \\
\hline \multirow[t]{3}{*}{ Residual } & $\begin{array}{l}\text { Correlation } \\
\text { Coefficient } \\
\end{array}$ & -028 & 031 & -058 & -036 & $733 * *$ & 1,000 \\
\hline & Sig. (2-tailed) & 779 & 761 & 566 & 722 & 000 & \\
\hline & $\mathrm{N}$ & 100 & 100 & 100 & 100 & 100 & 100 \\
\hline
\end{tabular}

* Correlation is significant at the 0.05 level (2-tailed).

** Correlation is significant at the 0.01 level (2-tailed).

Berdasarkan tabel 4.16 tersebut diatas, pada kolom Residual dapat dilihat bahwa nilai Correlation Coefficient adalah rendah atau nilai signifikan (Sig. (2-tailed)) masing-masing variabel independen diatas $5 \%$, maka masing-masing variabel independen (Variabel Pembiayaan Mudharabah, Variabel Pembiayaan Musyarakah, Variabel Pembiayaan Murabahah, Variabel Pembiayaan AlQardh) tidak mempunyai hubungan dengan residualnya. Dengan demikian, dapat disimpulkan bahwa tidak terdapat Heterokedastisitas pada model regresi yang diperoleh.

\section{Pembahasan}

Pertama, berdasarkan hasil uji variable pembiayaan mudharabah menunjukan bahwa variable pembiayaan mudharabah memiliki pengaruh signifikan dan positif terhadap variable peningkatan pendapatan masyarakat dengan nilai siginifikansi $0,002<0,005$ dan nilai $\mathrm{t}$ hitung sebesar 0,755>0,200.

Kedua, berdasarkan hasil uji variable pembiayaan musyarakah menunjukan bahwa variable pembiayaan musyarakah memiliki pengaruh signifikan dan positif terhadap variable peningkatan pendapatan masyarakat dengan nilai siginifikansi 0,000 $<0,005$ dan nilai t hitung sebesar 6,051 $>$ 0,200 .

Ketiga, berdasarkan hasil uji variable pembiayaan murabahah menunjukan bahwa variable pembiayaan murabahah memiliki pengaruh signifikan dan positif terhadap 
variable peningkatan pendapatan masyarakat dengan nilai siginifikansi 0,001 $<0,005$ dan nilai t hitung sebesar 0,232 > 0,200 .

Keempat, berdasarkan hasil uji variable pembiayaan al-qardh menunjukan bahwa variable pembiayaan al-qardh memiliki pengaruh signifikan dan positif terhadap variable peningkatan pendapatan masyarakat dengan nilai siginifikansi 0,002 $<0,005$ dan nilai $\mathrm{t}$ hitung sebesar 0,842 > 0,200 .

Kelima, secara simultan variable penyaluran dana (pembiayaan mudharabah, pembiayaan musyarakah, pembiayaan murabahah, pembiayaan al-qardh) mempunyai pengaruh yang signifikan terhadap peningkatan pendapatan masyarakat dengan nilai signifansi 0,000 . Kemudian kontribusi variable independen (Variabel Pembiayaan Mudharabah, Variabel Pembiayaan Musyarakah, Variabel Pembiayaan Murabahah, dan Variabel Pembiayaan Al-Qardh) terhadap naik turunnya atau variasi variabel dependen (Variabel Peningkatan Pendapatan Masyarakat) adalah sebesar $35,1 \%$ dan sisanya sebesar $64,9 \%$ merupakan sumbangan dari variabel lain yang tidak dimasukan kedalam model yang diajukan dalam penelitian ini (terkumpul dalam variabel error $/ \varepsilon$ ).

\section{E. Kesimpulan dan Saran \\ 1. Kesimpulan}

Berdasarkan hasil penelitian dan pembahasan, maka dapat diambil kesimpulan bahwa sebagai berikut:

a. Variabel Pembiayaan Mudharabah yaitu menunjukan bahwa variabel pembiayaan mudharabah memiliki pengaruh signifikan dan positif terhadap variabel peningkatan pendapatan masyarakat dengan nilai siginifikansi $0,002<0,005$ dan nilai t hitung sebesar 0,755 $>0,200$.

Maka H0 ditolak dan hipotesis penelitian diterima, yang artinya pembiayaan mudharabah mempunyai pengaruh signifikan terhadap peningkatan pendapatan masyarakat wilayah Bogor.

b. Variabel Pembiayaan Musyarakah yaitu menunjukan bahwa variabel pembiayaan musyarakah memiliki pengaruh signifikan dan positif terhadap variabel peningkatan pendapatan masyarakat dengan nilai siginifikansi $0,000<0,005$ dan nilai t hitung sebesar 6,051>0,200. Maka H0 ditolak dan hipotesis penelitian diterima, yang artinya pembiayaan musyarakah mempunyai pengaruh signifikan terhadap peningkatan pendapatan masyarakat wilayah Bogor.

c. Variabel Pembiayaan Murabahah yaitu menunjukan bahwa variabel pembiayaan murabahah memiliki pengaruh signifikan dan positif terhadap variabel peningkatan pendapatan masyarakat dengan nilai siginifikansi $0,001<0,005$ dan nilai t hitung sebesar 0,232 >0,200. Maka H0 ditolak dan hipotesis penelitian diterima, yang artinya pembiayaan murabahah mempunyai pengaruh signifikan terhadap peningkatan pendapatan masyarakat wilayah Bogor.

d. Variabel Pembiayaan Al-Qardh yaitu menunjukan bahwa variabel pembiayaan al-qardh memiliki pengaruh signifikan dan positif terhadap variabel peningkatan pendapatan masyarakat dengan nilai siginifikansi $0,002<0,005$ dan nilai $t$ hitung sebesar $0,842>0,200$. Maka H0 ditolak dan hipotesis penelitian diterima, yang artinya pembiayaan al-qardh mempunyai pengaruh signifikan terhadap 
peningkatan pendapatan masyarakat wilayah Bogor.

e. Dapat disimpulkan bahwa pengaruh variabel pendapatan masyarakat sebelum mendapatkan penyaluran dana atau pembiayaan dari BMT bernilai kecil atau rendah dan setelah diberikan pembiayaan oleh BMT pendapatan masyarakat wilayah Bogor bernilai tinggi dan terbukti dari hasil uji pengaruh diatas yang menunjukan hasil signifikan dan positif.

\section{Saran}

Saran yang dapat diajukan berdasarkan kesimpulan diatas adalah sebagai berikut:

a. Bagi Pihak Baitul Maal Wattamwil wilayah Bogor:

1) Agar lebih meningkatkan pelayanan untuk pembiayaannya dengan cara lebih mempermudah anggota/nasabah yang mengajukan pembiayaan.

2) Tingkatkan kepercayaan kepada masyarakat agar masyarakat tidak ragu untuk menyimpan dananya di BMT.

3) Pacu motivasi para anggota atau nasabah dengan memberikan penyuluhan/pembinaan baik itu mengenai BMT itu sendiri atau pun tentang peningkatan kualitas berwirausaha.

b. Bagi Anggota/Nasabah BMT:

a. Pihak BMT tidak pernah ragu dalam menyalurkan dananya bagi masyarakat.

b. Pihak BMT pun selalu memberikan fasilitas kepada para anggota atau nasabahnya agar dapat lebih maju dalam berwirausaha dan selalu istiqomah dengan diniyah islamiyah.

c. Sesuai tujuan dari masing-masing BMT yaitu membantu men- sejahterakan masyarakat kecil atau dhuafa, pihak BMT tidak pernah luput untuk membantu masyarakat dalam meningkatkan kesejahteraan masyarakat dengan memberikan bantuan penyaluran dana atau pembiayaan kepada masyarakat yang tidak memberat-kan masyarakat.

\section{Daftar Pustaka}

Afrianto. 2010. Analisa Pengaruh Pembiayaan BMT terhadap Pendapatan UKM di Depok. Skripsi Mahasiswa STEI Tazkia.

Amalia, Euis. 2007. Sejarah Pemikiran Ekonomi Islam. Jakarta: Granada Press

Aminullah, Rifqi Arief. 2009. Peranan Baitul Maal Wattamwil (BMT) untuk Mencapai Kesejahteraan Anggotanya: Studi Kasus pada BMT Darussalam Ciamis, Jawa Barat. Skripsi Mahasiswa Universitas Islam Indonesia Yogyakarta.

Andriani. 2005. Baitul Maal Wattamwil: Konsep dan Mekanisme di Indonesia. Empirisma, Vol. 14, No. 2

Ansori, Abdul Ghofur. 2007. Perbankan Syariah di Indonesia. Jakarta: Gadjah Mada University Press.

Antonio, Muhammad Syafi'i. 2003. Bank Syariah dari Teori ke Praktek. Jakarta: Gema Insani Press.

Arifin, Zainal. 2000. Memahami Bank Syariah: Lingkup, Peluang, Tantangan dan Prospek. Jakarta: Alvabet. Pp. 137.

Budi, Triton Prawita. 2006. SPSS 15.0, Terapan: Riset Statistik Parametik. Yogyakarta.

Chapra, Muhammad Umar. 2001. Pandangan Islam terhadap Kesejahteraan Ekonomi Muslim. Jakarta. 
Dahlan, Abdul Aziz, et.al. 1999. Ensiklopedia Hukum Islam. Cetakan Kedua. Jakarta: PT Ichtiar Baru Van Hoeve.

Ferdinand, Augusty. 2006. Metode Penelitian Manajemen. Semarang: Badan Penerbit Undip.

Ghozali, Imam. 2006. Aplikasi Analisis Multivariate dengan Program SPSS. Edisi ke-3. Semarang: Badan Penerbit Universitas Diponegoro.

Gujarati, Damodar. 2003. Ekonomertika Dasar. Jakarta: Penerbit Erlangga.

Hakim, Cecep Maskanul. 1995. Konsep Pengembangan Baitul Maal. Paper Seminar Ekonomi Islam, ICMI Bandung.

Hakim, Syekh Luqman. 2008. Pengaruh Pembiayaan terhadap Pendapatan Pengusaha Mikro: Studi Kasus Koperasi BMT Tadbirul Ummah Bogor. Skripsi Mahasiswa STEI Tazkia.

Hilman, Haidi. 2009. Pengaruh Pembiayaan BMT terhadap Perkembangan Usaha Nasabah: Studi Kasus pada BMT Wihdatul Ummah Bogor. Skripsi Mahasiswa STEI Tazkia.

Karim A. 2004. Bank Islam: Analisis Fiqh dan Keuangan. Jakarta: Raja Grafindo Persada.

Kasmir. 2008. Bank dan Lembaga Keuangan Lainnya. Jakarta: PT. RajaGrafindo Persada.

Latif, A. Azharuddin. 2005. Fiqh Muamalah. Jakarta: UIN Jakarta Press.

Mudrajad, Kuncoro. 2003. Metode Riset untuk Bisnis dan Ekonomi. Jakarta: Erlangga.

Perwaatmadja, Karnaen dan Antonio, Muh. Syafi'i. 1992. Apa dan Bagaimana
Bank Islam. Yogyakarta: Dana Bhakti Wakaf.

Perwataatmadja, Karnaen A. 1996. Membumikan Ekonomi Islam di Indonesia. Depok: Usaha Kami.

Prawira, Dicky Yudha. 2010. Pengaruh Pembiayaan terhadap Peningkatan Pendapatan Pedagang: Studi Kasus pada Koperasi Pasar Tanah Abang Syariah. Skripsi Mahasiswa STEI Tazkia.

PSAK No.59 Tahun 2002

PSAK Nomor 59 Tahun 2002.

Qardhawi, Yusuf. 1997. Norma dan Etika Ekonomi Islam. Jakarta: Gema Insani Press.

Ridwan M. 2004. Manajemen Baitul Maal Wa Tamwil. Yogyakarta: UII Press.

Saefuddin, Muflih. 1992. Strategi Pemberdayaan UKM (Iklim Usaha, Pembinaan, Pendanaan dan Kemitraan). Makalah dan Seminar Pemberdayaan Ekonomi Rakyat, Widya Graha LIPI.

Santoso, Singgih. 2002. Buku Latihan SPSS

Statistik Non Parametik. Jakarta: Penerbit PT Elex Media Komputindo Kelompok Gramedia.

Sirait, Bonar. 2009. Analisa Pengaruh Program Dinas Koperasi dan UKM terhadap Perkembangan Koperasi, Usaha Mikro, Kecil dan Menengah di Sumatera Utara. Tesis Mahasiswa Pasca Sarjana Universitas Sumatera Utara.

Suharto, Edi. 2006. Pekerjaan Sosial di Dunia Industri Memperkuat Tanggungjawab Sosial Perusahaan (Corporate Social Responsibility). Bandung: Refika Anditama.

Suhendi H. 2004. Strategi Optimalisasi Peran BMT Sebagai Penggerak Sektor Usaha Mikro. 
Sumiyanto, Ahmad. 2008. BMT Мепијu Koperasi Modern. Yogyakarta: ISES.

Umar, H. 2005. Riset Pemasaran dan

Perilaku Konsumen. Jakarta:

Gramedia Pustaka Utama.

Undang-Undang Nomor 10 Tahun 1998.

Usman, Rachmadi. 2002. Aspek-Aspek Hukum Perbankan Islam di Indonesia. Bandung: PT Citra Aditiya Bakti.

Zallum, Abdul Qadim. 1983. Al-Amwal Fi Daulah Al-Khilafah. Cetakan Pertama. Beirut: Darul 'Ilmi Lil Malayin.

Zastrow, Charles H. 2000. Introduction to Social Work and Social Welfare. $7^{\text {th }}$ Edition. Pacific Grove: Brooks/Cole. www.bi.go.id, yang diakses pada tanggal 10 Maret 2012.

www.pinbukpress.com 